\title{
Fringe Benefits for Academic Library Personnel
}

\begin{abstract}
This paper reports the results of a survey on fringe benefits provided by college and university libraries. Sixty-five of 120 questionnaires were returned from college libraries across the country. Benefits treated are: vacations, sick leave, faculty rank, salaries, sabbatical, yearly increments, raises on merit, time off for funerals, voting, and jury duty.
\end{abstract}

B ENEFITS FOR LIBRARY personnel, as in other kinds of organizations, are constantly being evaluated in the light of their usefulness to personnel. Many library administrators have not become aware of the need for good fringe benefits in recruiting and maintaining library staff. An assiduous search of library literature on benefits for academic librarians did not reveal a sufficient amount of information to assist one in formulating a policy.

While public school librarians have identified with teachers, academic librarians have for years attempted to identify themselves with college faculty, in order to gain the quite considerable benefits that could come from faculty status-including short hours, time for independent research, grants for study programs, long vacations, tenure rights, as well as association with such prestigious groups as the American Association of University Professors. As faculty, also, librarians would come under the protection of the accrediting agencies, which can sink a school's reputation if it mistreats its faculty members. ${ }^{1}$

Mr. Wright is Branch Librarian, Rochester Public Library.
Liberal fringe benefits will lessen (but not eliminate) recruiting problems. As fringe benefits have become increasingly important, periodic reviews have been made within private employment, government, and senior colleges and universities that facilitate comparison and improvement of their fringe benefits. ${ }^{2}$ This article came about as the result of a survey conducted to assist in formulating a more sophisticated benefits policy for library personnel at Alabama Agricultural \& Mechanical College. Of 120 questionnaires sent to academic libraries across the country, sixty-five were returned. The distribution of replies was representative, with small and large, private and public, institutions well represented, ranging from Benedict College and Delaware State College, with enrollments of less than 2,000 students, through Hampton Institute and Iowa State (under 5,000), to North Dakota State and Wyoming, on up to Purdue and Illinois and California. No attempt is made here to capsulize the entire survey. ${ }^{3}$

Library staff is described as professional and nonprofessional: professional staff is defined as possessing a master's 
degree in library science, and nonprofessional includes all other staff. There did not seem to be a great amount of difference in benefits offered by large and small institutions. The only significant difference was in the hours of operation, with larger institutions requiring longer hours. It appears that academic administrators are working diligently to improve benefits of library employees. With the increasing unionization of library employees, administrators might be well advised to get their houses in order.

\section{Benefits of Major Interest}

Library employees seem to place greater importance on vacation, sick leave, faculty rank, and salaries as compared with sabbaticals and several other items.

TABLE 1

Sick Leave

\begin{tabular}{lcc}
\hline \hline Time & $\begin{array}{c}\text { Professional } \\
\text { (Percent) }\end{array}$ & $\begin{array}{c}\text { Nonprofessional } \\
\text { (Percent) }\end{array}$ \\
\hline 10-15 days & 38 & 56 \\
1 month & 19 & 16 \\
60-90 days & 2 & 2 \\
As needed & 23 & 8 \\
No policy & 17 & 18 \\
& Cumulative Sick Leave \\
& (Percent) & \\
& Yes & 62 \\
& No & \\
& No policy 17 & \\
\hline
\end{tabular}

The majority of institutions grant from ten to fifteen days sick leave for both professionals and nonprofessionals, with days computed on a day-permonth basis. Most Alabama and predominantly Negro colleges have no policy whatsoever regarding sick leave. Only 4 percent give a bonus day for staff members who had no sick days the previous year.

It should be pointed out that 100 percent answered "yes" to the question of providing for staff to attend professional meetings. It was not clear in their an- swers as to whether all expenses are paid, or if time off, only, is allowed. Most academic libraries provide for one or two staff members to attend meetings at the school's expense, but it is usually limited to the library's administrators, with other members of the staff attending at their own expense.

There should be a policy to permit attendance at professional meetings which includes all levels of the library staff. A suggested method is a rotating system whereby members of the staff are selected on the basis of a combination of factors-years of service with the institution, attendance at previous meetings at one's own expense, contributions to professional literature, and most certainly, membership in the organization. In March, 1969, institutions of higher learning in the state of Alabama that are under the direction of the State Board of Education were informed that no employees of these institutions were to attend any more meetings at state expense until further notice. A policy of this nature certainly imperils recruitment and retention of a competent staff.

TABLE 2

Paid Vacation Time for 12-Month EMPLOYEES

\begin{tabular}{lcc}
\hline \hline Time Allotted & $\begin{array}{c}\text { Professional } \\
\text { (Percent) }\end{array}$ & $\begin{array}{c}\text { Nonprofessional } \\
\text { (Percent) }\end{array}$ \\
\hline 2 weeks & 10 & 69 \\
3 weeks & 6 & 12 \\
1 month & 65 & 12 \\
5 weeks & 19 & 7 \\
\hline
\end{tabular}

It is interesting to observe that 65 percent of the professionals received one month of vacation time and 19 percent received as much as five weeks depending on length of employment, while 69 percent of nonprofessionals received only two weeks. In almost every case, professionals received more vacation than nonprofessionals. In some instances, librarians were employed on a nine to ten month basis and were not therefore considered for a paid vacation. 
TABLE 3

LeNGTH OF EMPLOyMENT Before VACATion

\begin{tabular}{lcc}
\hline \hline Time Allotted & $\begin{array}{c}\text { Professional } \\
\text { (Percent) }\end{array}$ & $\begin{array}{c}\text { Nonprofessional } \\
\text { (Percent) }\end{array}$ \\
\hline Immediately & 28 & 16 \\
6 months & 26 & 35 \\
7-11 months & 10 & 9 \\
1 year & 36 & 42 \\
\hline
\end{tabular}

It seems clear from Table 3 that the length of employment before vacation varied sharply between professionals and nonprofessionals, with 28 percent of the professionals receiving some vacation immediately, compared to only 16 percent for nonprofessionals. However, the most common length of employment before any vacation for both professional and nonprofessional staff was one year.

TABLE 4

OTHER IMPORTANT BENEFITS

\begin{tabular}{ccc}
\hline \hline Benefits & $\begin{array}{c}\text { Yes } \\
\text { (Percent) }\end{array}$ & $\begin{array}{c}\text { No } \\
\text { (Percent) }\end{array}$ \\
\hline
\end{tabular}

Librarians with faculty rank

Salaries commensurate with faculty

Sabbaticals commensurate with faculty

Yearly increments

Raises on merit
73

80

54

98

79

\section{7}

20

46

2

There were other items which were of interest, and it was found that fewer libraries had any policy at all regarding these benefits. It seems clear from this table that the majority answered "yes" to the questions, but not as great a majority as we would hope for. A 100 percent "yes" to each of these benefits would not be unreasonable.

It should be noted that where employees received 1 to 4 days off for funerals, it was never more than one day for funerals of friends. It is significant to observe that most libraries do not have any policy on time due to attend funerals; it might be that library administrators do not consider them as they do other days off, and are willing to ar- range for employees as much time as needed for such unfortunate circumstances. However, it would make for consistency in dealing with staff to have some type of policy.

\section{TABLE 5}

Time OfF for Funerals of Relatives AND FRIENDS

\begin{tabular}{lrrrr}
\hline \hline Time Allotted & \multicolumn{2}{c}{$\begin{array}{c}\text { Relatives } \\
\text { Prof. } \\
\text { (Penpront) }\end{array}$} & \multicolumn{2}{c}{$\begin{array}{c}\text { Friends } \\
\text { Prof. } \\
\text { (Percent) }\end{array}$} \\
\hline 1 hour-1/2 day & - & - & 12 & 12 \\
1-4 days & 34 & 37 & 8 & 8 \\
Week plus & 4 & 3 & $\overline{6}$ & $\overline{5}$ \\
As needed & 10 & 8 & 6 & 74 \\
No policy & 51 & 45 & 73 & 74 \\
\hline
\end{tabular}

TABLE 6

JuRY DUTY

\begin{tabular}{lcc}
\hline \hline Time Allotted & $\begin{array}{c}\text { Professional } \\
\text { (Percent) }\end{array}$ & $\begin{array}{c}\text { Nonprofessional } \\
\text { (Percent) }\end{array}$ \\
\hline Up to 2-3 weeks & 2 & 2 \\
Salary cut if paid & 2 & 2 \\
As needed & 76 & 76 \\
No policy & 19 & 19 \\
\hline
\end{tabular}

TABLE 7

Voting

\begin{tabular}{lcc}
\hline \hline Time Allotted & $\begin{array}{c}\text { Professional } \\
\text { (Percent) }\end{array}$ & $\begin{array}{c}\text { Nonprofessional } \\
\text { (Percent) }\end{array}$ \\
\hline 1-3 hours & 15 & 15 \\
1 day & 3 & 3 \\
As needed & 28 & 28 \\
No policy & 52 & 52 \\
Holiday & 2 & 2 \\
\hline
\end{tabular}

It is the consensus of college administrators that a call for one to serve as a juror is a responsibility, and most are given as much time as needed to serve. Only 2 percent cut salary if the staff member is paid to serve.

For voting time, 52 percent had no policy on the amount of time one should have, and 28 percent gave as much time as needed. Giving as much time as needed and having no policy at all could result in having too many key members of the staff away at the same time; it would be well to have a very liberal policy on the amount of voting time. 


\section{Summary and Recommendations}

It is clear from this survey that benefits for college library personnel are varied and somewhat limited. A large number of colleges reported no policy on many benefits that are generally considered important to employees. It appears that many library administrators are in the process of presenting recommendations to college administrators on fringe benefits and have no frame of reference to assist in these recommendations. Since, to my knowledge, this was the first nationwide study on fringe benefits to academic personnel, a number of questions about fringe benefits cannot be answered. Further study is needed to answer these questions. Some of them are:
1. How do fringe benefits for academic librarians compare with those of private and governmental employees?

2. What are the effects of fringe benefits in recruiting and maintaining library staff?

3. What are the benefits most desired by academic library personnel?

If these questions are answered in a future study, library and college administrators will be able to formulate more rational and relevant benefit policies.

\section{REFERENCES}

1. Karl Nyren, "Libraries and Labor Unions," Library Journal, vol. 92, no. 11 (June 1, 1967), 2115.

2. C. W. Robert, "Fringe Benefits in Public Junior Colleges," Junior College Journal, vol. 39 (October 1968), 28.

3. Free copies of the completed survey may be obtained from the author, Rochester Public Library, 115 South Avenue, Rochester, New York 14604. 